doses of ${ }^{3} \mathrm{H}$-thymidine in excess of those required by the agreed protocols in the treatment of cancer patients; failure to obtain the informed consent of 112 patients to an experimental treatment; the treatment of 27 patients with ${ }^{3} \mathrm{H}$-thymidine for breast cancer which was not one of the conditions specified in the protocol; and failure to keep complete $\mathrm{X}$-ray records. $\mathrm{Dr}$ DeVita agreed that "all the allegations are curious and, if true, reprehensible".

The committee asked three broad questions. Why had the NIH investigation taken three years to bring nearly to completion? Why had Dr Strauss not been denied a further grant simply on the grounds that serious allegations had been made against him? And what would happen if the allegations were substantiated?

Dr DeVita admitted that "we were too slow off the mark" and also that "with the benefit of hindsight" it would have been wise to have told the advisory committee (a few weeks after becoming director of $\mathrm{NCI}$ ) that Dr Strauss's Boston record was being investigated, even though that would probably have meant that the $\$ 910,000$ grant would not have been made. But he insisted that his discomfort before the committee was matched by his discomfort at "the idea of judging someone guilty until the investigation is complete".

Meanwhile, Dr DeVita said, procedures at NCI have been tightened up, with contracts reviewed by a central financially oriented staff. All contracts will in future be subject to peer review and he personally will take responsibility for seeing that funds are properly spent. If the allegations against Dr Strauss are proved, it seems there will still be time to recover $\$ 600,000$ of the 1980 grant.

\section{Vive la différence!}

M. Pascal Clément would like French scientists to speak more French, s'il vous plait. In his report on the state of the French language, commissioned by the then President Giscard d'Estaing and presented recently to President Mitterand, M. Clément - a parliamentarian and member of Giscard's Union pour le Democratie Française - devotes a whole chapter to the invasion of English into science in France. French scientists are lazy about translating English technical terms, says Clément, preferring a kind of "Franglais"; and they even write their papers in English.

Something must be done, the report demands. Clément suggests that conferences conducted in English without translation facilities should get no support from state funds. This - if it ever took effect - would worry the Centre National de la Recherche Scientifique which supports much of the basic science in France; for two-thirds of

\section{US astronomy \\ Prospects for people}

\section{Washington}

Anxiety about the future of astronomy in the United States is one of the recurrent themes in the final draft of the National Research Council report of the Astronomy Survey Committee. The committee, whose chairman is $\mathrm{Dr}$ George B. Field from the Harvard/Smithsonian Center for Astrophysics, has now submitted its fifth draft to the review procedures of the National Academy of Sciences.

The final draft is especially concerned about the plight of those astronomers who have been employed on fellowships or whose salaries have been charged to project grants for periods as long as six or eight years, and whose careers are now threatened by declining budgets. Astronomy differs from other fields of science in that there are no natural industrial outlets for academic astronomers, while universities are often unwilling as well as unable to employ such relatively senior people.

The draft report recommends a system of assistant professorships financed jointly by universities and the federal government. The acceptability of this proposal, for which there is no precedent in the United States, has yet to be determined.

The Field Committee also plans a series of recommendations of priorities for the future development of astronomy. Predictably it puts its weight behind the space telescope, but urges that support should also be given to second-generation instruments for the device. The launching of a $\gamma$-ray observatory (by NASA) and the building of the proposed 25-metre

papers read at its conferences are read in English, while only one in five conferences have translators present.

Scientists have reacted to Clément's strictures with amused smiles. $\mathrm{He}$ is naive, they say. Much as they would like to speak and write in their native tongue, French scientists constitute only a tiny fraction of the world's scientists ( 7 per cent, estimates one). And any scientist worth his or her salt in France will be collaborating with groups abroad, with half of them probably American. And how many Americans can read or speak French?

Moreover, the inflexible attitude of people like Clément towards their language probably does more to help English penetrate French than hinder it, they say. For this attitude sees mistakes of foreigners attempting to speak French as fautes - faults - in the speaker, thus embarrassing some who would otherwise try to get by in the language.

As for the consequences of the report on French science, the thing is une lettre morte already.

Robert Walgate millimetre-wave telescope are in the list of projects to be pursued, and there is a cautious welcome for the Princeton proposal to construct a gallium detector for solar neutrinos.

Further ahead, the Field Committee apparently wishes to give priority to an $\mathrm{X}$-ray observatory even more advanced than Einstein and to a "new technology" telescope for optical and infrared observations. The proposal to deploy a 10-metre dish in an orbit about the Earth is put next on the list. The draft report has much to say about the need for technical and supporting services for the development of these projects.

Publication of the report is unlikely before October.

\section{Uranium enrichment US price hike?}

\section{Washington}

The question whether the United States should charge customers for enriched uranium more than the bare cost of enrichment surfaced again last week in the House of Representatives, this time because Congress is looking for ways of raising extra revenue so as to relieve the budgetary dilemmas forced on it by the Administration. But the chances of raising extra money quickly are small. And the Administration is clearly divided within itself about the merits of the proposal.

The charge for enrichment services at government enrichment plants has been a controversial issue since 1974 , when it was planned that responsibility for nonmilitary enrichment should be transferred to the private sector, and when everybody agreed that government prices should not undercut those of private manufacturers.

Last week, Congressman Richard L. Ottinger, chairman of the House Subcommittee on Energy Conservation and Power, opened a brief and hastily arranged enquiry on the subject with the blunt confession that the House Budget Committee needed to know this week whether the price of enriched uranium should be increased. One of his difficulties was that the Department of Energy, which argued for an increase of price in 1978, has now changed its mind. Dr William $R$. Voigt, who put the department's case for an increase three years ago, last week argued that the rules for enrichment pricing should not be changed simply so that Congress could spend more on other energy projects.

The General Accounting Office has been more consistent. In April, the director of the Office, Dr Dexter Peach, argued for prices that would take account of what private companies would have to set aside for state and federal taxes and for making a return on capital. His April calculation, repeated last week, was that the US enrichment business, now worth $\$ 1,300$ million a year, would yield an extra $\$ 1,300$ million 
between now and October 1986, one-third of that from overseas.

The nuclear industry (represented last week by the Edison Electric Institute) objects to the proposed increases of price partly on legal grounds - the amended Atomic Energy Act would have to be amended again - and partly on the grounds that a change in the price structure for enrichment services should be part of a more general review.

The costs of enrichment are already due to increase by 18 per cent from October. The proposed "fair pricing" increase would amount to a further 15 per cent, implying an increase of the cost of electricity generated by nuclear stations of between 1 and 2 per cent. Such an increase would not be decisive, which is why the decision on fair pricing may eventually turn on the competitiveness of US enrichment. Dr Peach quoted last week the latest prices charged by Eurodif as $\$ 127$ for a unit of separative work. For the first time, US enrichment is not the world's cheapest.

\section{UK nuclear power}

\section{Missed again}

The ailing nuclear construction industry in Britain, which suffered a ten-year gap in orders in the 1970s and over-committed itself to the advanced gas-cooled reactor, may now even be denied a quick entry to American pressurized water technology. For orders for key parts of the proposed Sizewell B nuclear power station - to be the first commercial pressurized water reactor (PWR) in the United Kingdom if it survives a public inquiry - may have to be placed abroad.

The reasons are cost and time. British industry is not tooled up to produce PWR components, in contrast with other companies - notably those in France, the United States and Germany - so costs will be higher and delays longer if orders are placed in the United Kingdom. Of the principal possible UK contractors, Babcock and Wilcox has indicated that it would need a government subsidy to compete with foreign suppliers; and Northern Engineering Industries has asked that foreign competition be ruled out.

Neither now seems likely. The "reference design"' and safety case for the Sizewell reactor prepared by the National Nuclear Corporation is now with the Nuclear Installations Inspectorate for first scrutiny, and it includes a major extension of safety features compared with its American model, the Westinghouse reactor under construction at Callaway, Missouri. The independent emergency core cooling systems have been multiplied, the containment vessel extended to a doublewall construction and more concrete introduced into the reactor floor area to protect workers from the relatively high radiation levels of PWRs compared with the old Magnox stations.

\section{French hiatus}

The French Prime Minister, M. Pierre Mauroy, has confirmed a "freeze" on nuclear power construction in France, and promised a "great debate" in the National Assembly which will question the role and cost of nuclear power in France relative to that of coal and other sources of energy. But the idea of a national referendum on the matter has been pushed to the back of the stage, and the new government has raised no opposition to a major nuclear commitment made by the previous administration.

For in the last few days before the newly elected socialist president took over at the Elysée, the outgoing Prime Minister, M. Raymond Barre, agreed to the doubling of the capacity of the principal French oxide fuel reprocessing plant at Cap de la Hague near Cherbourg, run by the company Cogema.

Cap de la Hague has in recent years been dogged by malfunction and minor accidents. Its existing UP2 400 plant for oxide fuel (as used in pressurized water reactors) was designed to handle 200 tonnes a year; but in five years of operation it has been able to reprocess only 250 tonnes.

M. Barre's decree, if not overturned by the Mitterand government, will allow Cogema to spend 20,000 million francs ( $£ 2,000$ million) on upgrading UP2 400 to UP2 800 (to handle 800 tonnes a year of spent oxide) and on building UP3, a completely new plant to handle an equal amount of spent fuel from overseas.

The technology of the new plant will be the same as before, but there will be parallel shearing and dissolution sections to give spare capacity if one part of the plant breaks down - small comfort perhaps for Cogema's six customers, Japan, West Germany, The Netherlands, Belgium, Switzerland and Sweden.

Some in France believe that the proposed national debate over nuclear matters could mean that the Cap de la Hague decision could be reopened, and that the decision to reprocess foreign fuel may be reexamined. Robert Walgate

Mr Brian George, who was recently appointed by the Central Electricity Generating Board to direct its interests in the PWR project, said on Monday that the board's approach to ordering for Sizewell might differ if it could clearly be seen to be part of a long programme of orders, for then it would be prudent to build up the UK nuclear industry. On the other hand, the first order might be the last. And $\mathrm{Mr}$ Reginald Flint, responsible for the reference design at the National Nuclear Corporation, confirmed that all orders for the PWR would have to be placed on a strictly commercial, competitive basis, with no preference for UK suppliers.

Robert Walgate

\section{Yugoslavian nuclear power}

\section{Locals late reacting}

The charging of Yugoslavia's first nuclear power station, at Krsko on the River Sava, has provoked a belated burst of opposition. During the construction of the reactor, a $664 \mathrm{MW}$ Westinghouse unit, local feeling was muted. But when charging with uranium fuel was about to begin, the reactor became an issue in the Yugoslav press.

Krsko lies on the border between the republics of Slovenia and Croatia, which jointly built the power station. The commission in charge of reactor safety is likewise an inter-republic body, made up of scientists from the Josef Stefan Physics Institute in Ljubljana and the Rudjer Boskovic Physics Institute in Zagreb.

According to the Yugoslav news agency Tanjug, the commission decided in April this year that the trial operation of the station scheduled for July would have to be postponed. The commission is said to have found that measures to protect the environment, the staff and the nearby population had not been implemented, that there was no proper procedure for evacuating the staff in an emergency and no proper fire-fighting equipment. Nor had the problems of storing radioactive waste and treating the coolant water been properly dealt with.

The following day, however, Tanjug reported that Dr Maurice Rosen, director of the International Atomic Energy Agency's reactor safety department, had announced that there were no "technological obstacles" to the charging of the station. Nine days later, the Slovenian and Croatian authorities gave permission for charging to go ahead.

According to the Zagreb press, the Yugoslav safety committee tried to insist that certain safety work which Westinghouse and the power station management had planned for after charging, should be done first, but the recommendations were ignored. Significantly, Vecernji list of 2 June quotes Dr Marko Brankovic, head of the Croatian Commission for the Human Environment, as saying, "We cannot play around with nuclear reactors as if they were 'political factories'. They must be perfect in every technological respect, or else they must not start"'. A "political factory", in Yugoslav slang, is a factory erected for prestige reasons, without proper attention to technological details and which proves to be a waste of the usually considerable investment.

Part of the present trouble may be caused by local misunderstanding of the distinction between the charging of a reactor and its start-up. There is also considerable concern about the highly polluted state of the Sava, from Krsko down to its confluence with the Danube. Rumour (downstream in Zagreb) at- 